\title{
IMPLEMENTATION OF AN ENHANCED RECOVERY PROGRAM AFTER BARIATRIC SURGERY: CLINICAL AND COST-EFFECTIVENESS ANALYSIS
}

\author{
Vanni Agnoletti ${ }^{1}$, Stefano Bonilauri ${ }^{2}$,Lesley De Pietri ${ }^{3}$, Demetrio Ferrara $^{3}$, Andrea Lanaia ${ }^{1}$, \\ Nicola Pipia ${ }^{4}$, Matteo Seligardi ${ }^{5}$, Emanuele Padovani ${ }^{6}$ and Ruggero Massimo Corso ${ }^{7}$
}

${ }^{1}$ Division of Anesthesiology and Intensive Care Unit, Department of Emergency, AUSL Romagna-Cesena, Cesena FC, Italy; ${ }^{2}$ General and Emergency Surgery, Department of General Surgery, Azienda Ospedaliera, IRCCS Arcispedale Santa Maria Nuova, Reggio Emilia, Italy;

${ }^{3}$ Division of Anesthesiology and Intensive Care Unit, Department of Cardiology, Thoracic and Vascular Surgery, Critical Care Medicine, Azienda Ospedaliera, IRCCS Arcispedale Santa Maria Nuova, Reggio Emilia, Italy;

${ }^{4}$ Operations Manager Istituto Clinico Humanitas Mater Domini,Varese, Italy;

${ }^{5}$ Intensive Care Unit, Azienda Ospedaliera, IRCCS, Arcispedale Santa Maria Nuova, Reggio Emilia, Italy;

${ }^{6}$ Business Administration/University of Bologna, Department of Management, Bologna, Italy;

${ }^{7}$ Department of Surgery, Anesthesia and Intensive Care Section, G.B. Morgagni Hospital, AUSL Romagna-Forlì, Forlì FC, Italy

\begin{abstract}
SUMMARY - Enhanced recovery after surgery (ERAS) programs are perioperative evidencebased interventions that have the purpose of making the perioperative pathway more efficient in safeguarding patient safety and quality of care. Recently, several ERAS components have been introduced in the setting of bariatric surgery (Enhanced Recovery After Bariatric Surgery, ERABS). The aim of the present study was to evaluate clinical efficiency and cost-effectiveness of the implementation of an ERABS program. It was a retrospective case-control study comparing a group of adult obese (body mass index $>40$ ) patients treated according to the ERABS protocol (2014-2015) with a historical control group that received standard care (2013-2014) in the General and Emergency Surgery Department, Arcispedale S. Maria Nuova Hospital, Reggio Emilia, Italy. Data on the occurrence of complications, mortality, re-admissions and re-operations were extracted retrospectively from medical case notes and emergency patient admission lists. Length of hospital stay was significantly different between the two cohort patients. In the control group, the mean length of stay was $12.6 \pm 10.9$ days, whereas in the ERABS cohort it was $7.1 \pm 2.9$ days $(p=0.02)$. During hospital stay, seven patients in the control group developed surgical complications, including one patient with major complications, whereas in the ERABS group three patients developed minor complications. Economic analysis revealed a different cost distribution between the two groups. On the whole, there were significant savings for almost all the variables taken into consideration, mainly driven by exclusion of using intensive care unit, which is by far more expensive than the average cost of post-anesthesia care unit. Our study confirmed the implementation of an ERABS protocol to have shortened hospital stay and was cost-saving while safeguarding patient safety.
\end{abstract}

Key words: Bariatric surgery; Enhanced recovery after surgery; Costs

\section{Introduction}

The escalating global epidemic of obesity all over the world challenges allocation of national healthcare resources ${ }^{1}$. Bariatric surgery is the most effective treat-
Correspondence to: Ruggero Massimo Corso, $M D$, Department of Surgery, Anesthesia and Intensive Care Section, G.B. Morgagni Hospital, V. le Forlanini 34, Forli, Italy

E-mail: rmcorso@gmail.com

Received April 18, 2018, accepted February 13, 2019 
ment for severe obesity, resulting in durable weight loss, as well as a positive impact on obesity-related comorbidities. As a result of the epidemic, the rate of surgical procedures worldwide increased from 146,000 in 2003 to 340,000 in 2011, with Roux-en-Y gastric bypass (RYGB) and sleeve gastrectomy accounting for $75 \%$ of all treatments ${ }^{2}$. The increased demand for bariatric surgery in the context of limited economic resources enforces adoption of good clinical practice guidelines aimed at optimizing the peri- and postoperative care of these patients ${ }^{3}$. Enhanced recovery after surgery (ERAS) programs are perioperative evidencebased interventions that have the purpose of making more efficient the perioperative pathway safeguarding patient safety and quality of care. ERAS pathways are designed to put the patient in the best possible conditions to deal with surgery, reduce surgical stress, and quickly bring it back to wellness ${ }^{4}$. ERAS programs, when implemented successfully, have resulted in a reduced length of hospital stay (LOS), reduced complications and better quality of life outcomes ${ }^{5-7}$. Recently, several ERAS components have been introduced in the setting of bariatric surgery (Enhanced Recovery After Bariatric Surgery, ERABS), and dedicated guidelines have been published ${ }^{8}$. However, although there are several studies documenting the feasibility of ERABS, the evidence for clinical efficiency and costeffectiveness is limited. The aim of the present study was to evaluate clinical efficiency and cost-effectiveness of the implementation of an ERABS program.

\section{Patients and Methods}

This was a retrospective case-control study comparing a group of adult obese (body mass index, (BMI) $>40)$ patients treated according to the ERABS protocol (2014-2015) with a historical control group that received standard care (2013-2014) in the General and Emergency Surgery Department, Arcispedale S. Maria Nuova Hospital, Reggio Emilia, Italy. The study was approved by the Institutional Review Board of the Arcispedale S. Maria Nuova, Reggio Emilia (protocol No. 2016/0014694). All patient data such as demographic details, baseline comorbidities, operations performed and LOS were obtained from the electronic hospital clinical database of surgical interventions (Easysalo ${ }^{\oplus}$ UniCODE srl Software Engineering). The matching parameters were sex, age, BMI and comor- bidities, and American Society of Anesthesiologists (ASA) physical status. The only exclusion criterion for both groups was patient refusal to participate in the study. The evaluation of cost variables (Table 1) was done in accordance with data provided by the Hospital. Data on the occurrence of complications (in accordance with Clavien-Dindo classification) $)^{9}$, mortality, re-admissions and re-operations were extracted retrospectively from medical case notes and emergency patient admission lists.

Table 1. Cost per variables

\begin{tabular}{|l|l|}
\hline Variable & Description \\
\hline Personnel cost & $\begin{array}{l}\text { Cost } p e r \text { patient/minute } \\
\text { Material cost } \text { per } \text { patient/single } \\
\text { surgery }\end{array}$ \\
Department LOS & Total LOS cost per patient/day \\
cost & Cost $p e r$ patient/day in ICU \\
ICU LOS cost & Cost $p e r$ patient/day in $\mathrm{PACU}$ \\
PACU cost & Total cost $p e r$ patient/minute \\
Overhead cost
\end{tabular}

LOS = length of stay; ICU = Intensive Care Unit; PACU = PostAnesthesia Care Unit

Patients in the ERABS group had their perioperative care managed according to the ERAS guidelines, while the control group followed the standard care established by the Department protocols. Patients in the ERABS and control groups were discharged once they had fulfilled the predetermined, standardized discharge criteria (Table 2). Decision on discharge was made by medical staff of the Hospital that were not involved in the study. The primary outcome was the mean LOS. Secondary outcomes included postoperative morbidity and mean cost per patient.

\section{Table 2. Discharge criteria}

Adequate pain relief with oral non-opioid analgesia
(paracetamol and etoricoxib)
No evidence for wound dehiscence or wound infection
No postoperative complication
Pulse rate $<90$ beats $/$ min, temperature $\leq 37.6^{\circ} \mathrm{C}$,
respiratory rate $<20$ breaths $/$ min
Uneventful technical procedure
Patient ambulatory
Drank 1 liter of water within $24 \mathrm{~h}$
Tolerating free oral fluids (e.g., milk)




\section{Statistical analysis}

Continuous data are reported as mean \pm standard deviation (range) and were compared using WilcoxonMann-Whitney test. Differences between the two groups for continuous variables were analyzed with Wilcoxon-Mann-Whitney test, while differences in dummy variables were analyzed with Fisher exact test. Statistical significance was set at $\mathrm{p}<0.05$. Statistical analyses were performed using IBMSPSS Statistics for Windows, Version 19.0 (IBM Corp., Armonk, NY, USA).

\section{Economic analysis}

We carried out economic analysis by classifying different cost centers where the patient was involved. The model uses time as the independent variable to define the value of the others, allowing to estimate the mean cost per minute for each variable taken into consideration. We assumed as given the mean cost of material (provided by the Arcispedale S. Maria Nuova administration and control board). Furthermore, the mean overhead cost per minute was obtained using the overall yearly overhead cost divided by the total utilization time of the operating theater. Regarding the staffing level and shifts, we estimated an average time and mix presence of personnel based on interviews conducted with medical staff. The results were used as baseline for the model assumptions, as follows:

- 2 surgeons = real time recorded by EasySalo Software

- 2 nurses $=$ time allocated equaled the time of surgery
$\Sigma$ [MATERIAL TOTAL ANNUAL COSTS + PERSONNEL COST SAt $^{+}$(OVERHEAD COST/AVERAGE TOTAL MINUTES $\left.S_{n}\right) * \Delta \mathrm{T}_{5}+\mathrm{ICU} \mathrm{LOS}_{2}$ COST + PACU LOS ${ }_{2} \operatorname{COST}+$ WARD $\left.\mathrm{LOS}_{\mathrm{p}} \mathrm{COST}\right]$

Variables $=$ variable directly related to the surgery taken into consideration

Variables $\Delta t=$ variable directly related to the surgery taken into consideration where value depends on time

Variablep= variable directly related to the entire pathway/procedure

\section{Fig. 1. Cost formula.}

- 1 anesthesiologist = real time recorded by EasySalo Software

- 1 nursing assistive staff = time allocated equaled the time of surgery

While we had to impute different absorption of resources in order to estimate the Total Operating Theater Cost, all other elements within the process (such as Intensive Care Unit (ICU), Post-Anesthesia Care Unit (PACU) and ward) were average costs given by the Hospital and already including utilization of different resources per patient. Nevertheless, the latter were adjusted as the function of time in order to be included in the model. Overall, the model allowed to highlight both the cost configuration and variable weights in the two different pathways and was designed as shown in Figure 1.

\section{Results}

There was no statistically significant difference at baseline between the two groups of patients for any study variable (Table 3 ). LOS was significantly different between the two patient cohorts. In the control group, the mean LOS was $12.6 \pm 10.9$ days, while in the ERABS group it was $7.1 \pm 2.9$ days $(\mathrm{p}=0.02)$.

Table 3. Baseline demographic and comorbidity variables

\begin{tabular}{|l|l|l|l|}
\hline Variable & Control group & ERABS group & p value \\
\hline Patients, N & 26 & 25 & \\
Female patients, n (\%) & $16(61.5)$ & $21(80.8)$ & $0.070^{*}$ \\
Age (yrs), mean (SD) & $46(10)$ & $41(11)$ & $0.146^{* *}$ \\
BMI, mean (SD) & $50.4(5.8)$ & $48(7.7)$ & $0.208^{* *}$ \\
Hypertension, n (\%) & $11(42.3)$ & $10(38.5)$ & $0.785^{*}$ \\
OSAS, n (\%) & $6(23.1)$ & $5(20)$ & $0.801^{*}$ \\
COPD, n (\%) & $6(23.1)$ & $2(8)$ & $0.147^{*}$ \\
Diabetes type 2, n (\%) & $5(19.2)$ & $6(24)$ & $0.691^{*}$ \\
Smoker, n (\%) & $5(19.2)$ & $6(24)$ & $0.691^{*}$ \\
\hline
\end{tabular}

$\mathrm{SD}=$ standard deviation; $\mathrm{BMI}=$ body mass index; OSAS = obstruction sleep apnea syndrome $\mathrm{COPD}=$ chronic obstructive pulmonary disease; ERABS = Enhanced Recovery After Bariatric Surgery; ${ }^{*} \mathrm{U}$ Mann-Whitney test; ${ }^{* *}$ t-test 
Table 4. Hospital stay and postoperative complications

\begin{tabular}{|l|l|l|l|}
\hline & ERABS & Control & p value \\
\hline $\begin{array}{l}\text { Length of stay (days) } \\
\text { Total complications } \\
\text { (n) } \\
\begin{array}{l}\text { Major complications } \\
\text { (n) }\end{array}\end{array}$ & $3.1 \pm 0.6$ & $12.6 \pm 2.1$ & $<0.001^{*}$ \\
\hline
\end{tabular}

*Wilcoxon-Mann-Whitney test; **Fisher exact test; ERABS = Enhanced Recovery After Bariatric Surgery

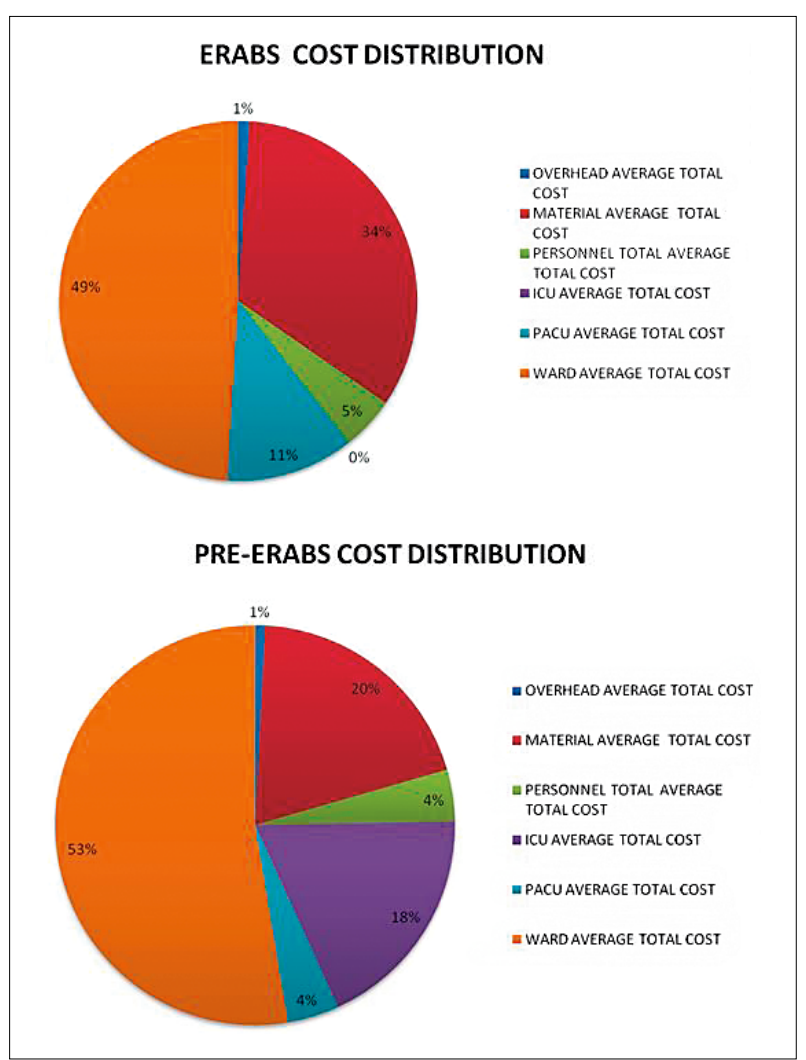

Fig. 2. Cost distribution.

During LOS, seven subjects in the control group developed surgical complications; one of them suffered major complication, Clavien-Dindo classification 3b, while in the ERABS group three patients developed minor complications, all classified as grade 2 of the Clavien-Dindo classification (Table 4).

Economic analysis revealed different cost distribution in the two groups. A greater proportion of the cost was generated by ICU stay and the associated personnel time and by material usage in the control group (Fig. 2). Another difference between the two groups

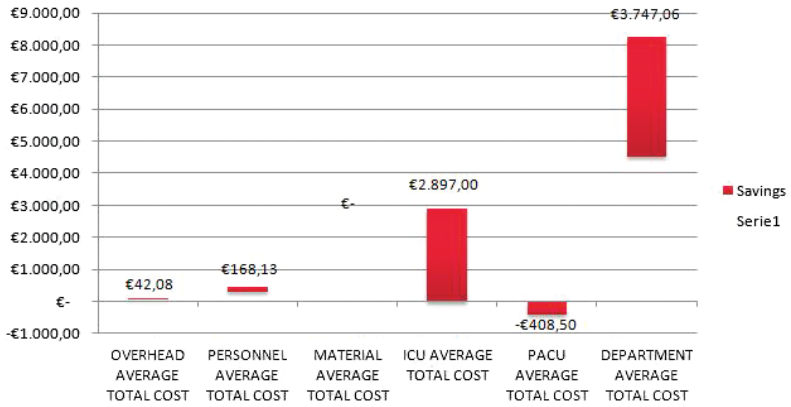

Fig. 3. Savings per variable in Enhanced Recovery After Bariatric Surgery, ERABS). vs. control group.

was related to the cost generated by PACU stay, which was higher in the ERABS group. On the whole, as shown in Figure 3, there were significant savings for almost all the study variables, mainly driven by exclusion of the use of ICU, the latter being by far more expensive than the average cost of PACU. The share of savings brought in by the new procedure compared with the control group was remarkable, reaching a total average of $5743 €$ saved per procedure. As shown in Figure 3, positive saving was recorded in four out of the six variables analyzed (overhead cost remained stable, accounting for only $1 \%$ of the total cost along with the material average total cost). It is important to mention that, although the material average total cost variable in our analysis was assumed as constant, reality suggests that the cost of material might increase slightly when using the new procedure.

\section{Discussion}

In the EU countries, health expenditure has been growing faster than the national income ${ }^{10,11}$. This can be attributed to the demand and supply side factors of population aging and medical innovation. The process of transforming resources into health outcomes is not efficient and it works as a factor contributing to the excessive growth of health expenditure. The use and application of efficiency concepts and programs to healthcare systems is not easy and sometimes it does not have an immediate impact on health outcomes. The application of ERAS protocols has a direct positive impact on performance of the healthcare services in terms of clinical quality indicators ${ }^{12}$. The implementation of ERAS principles in the bariatric surgery set- 
tings has demonstrated the same positive clinical impact ${ }^{13}$, but evidence for the cost-saving effect is limited. In our study, the introduction of an evidence based protocol for perioperative care of obese patients eligible for bariatric surgery has allowed significant reduction of hospital stay and associated costs by improving the efficiency safeguarding patient safety. Some limitations of the study should be emphasized in addition to its retrospective design. Cost trends over time were not included in the analysis, which was delimited to the 2015 cost report. This did not allow to take into consideration ongoing trends of surgery time reductions (which would result in cost reduction), if any. We estimated the time of surgery matched to the time imputed to nurses within the operating theater. However, this did not take into consideration differences that might occur in the awakening time after surgery. The sample size was small because of the large proportion of cases still treated with the traditional approach. Caution is therefore necessary in drawing conclusions on complications. Our study showed the implementation of the new protocol (ERABS) to have ensured significant saving in four out of the six variables taken into consideration. Greater saving was obtained by preventing patient admission to the ICU, which was the most costly patient pathway step.

\section{Conclusions}

Our study confirmed that the implementation of the ERABS protocol shortened hospital stay and was costsaving safeguarding patient safety. Future research should investigate the efficacy and safety of systematic implementation of this approach, defining the costs associated with the individual items of the program.

\section{References}

1. Arroyo-Johnson C, Mincey KD. Obesity Epidemiology Worldwide. Gastroenterol Clin North Am. 2016;45(4):571-9. DOI: 10.1016/j.gtc.2016.07.012

2. Buchwald H, Oien DM. Metabolic/bariatric surgery worldwide. Obes Surg. 2011;23:427-36. DOI: 10.1007/s11695-0120864-0
3. Petrini F, Di Giacinto I, Cataldo R, Esposito C, Pavoni V, Donato P, Trolio A, Merli G, Sorbello M, Pelosi P; Obesity Task Force for the SIAARTI Airway Management Study Group. Perioperative and periprocedural airway management and respiratory safety for the obese patient: 2016 SIAARTI Consensus. Minerva Anestesiol. 2016;82(12):1314-35.

4. Abeles A, Kwasnicki RM, Darzi A. Enhanced recovery after surgery: current research insights and future direction. World J Gastrointest Surg. 2017;9(2):37-45. DOI: 10.4240/wjgs.v9. i2. 37

5. Wind J, Polle SW, Fung KonJin PH, et al.; Laparoscopy and/or fast track multimodal management versus standard care (LAFA) study group; Enhanced Recovery after Surgery (ERAS) group. Systematic review of enhanced recovery programmes in colonic surgery. Br J Surg. 2006;93:800-9. DOI: 10.1002/bjs.5384

6. Muller S, Zalunardo MP, Hubner M, et al.; Zurich Fast Track Study Group. A fast-track program reduces complications and length of hospital stay after open colonic surgery. Gastroenterology. 2009;136:842-7. DOI: 10.1053/j.gastro.2008.10.030

7. Gustafsson UO, Hausel J, Thorell A, et al.; Enhanced Recovery after Surgery study group. Adherence to the enhanced recovery after surgery protocol and outcomes after colorectal cancer surgery. Arch Surg. 2011;146:571-7. DOI: 10.1053/j.gastro. 2008.10.030

8. Thorell A, MacCormick AD, Awad S, Reynolds N, Roulin D, Demartines N, Vignaud M, Alvarez A, Singh PM, Lobo DN. Guidelines for Perioperative Care in Bariatric Surgery: Enhanced Recovery After Surgery (ERAS) Society Recommendations. World J Surg. 2016;40(9):2065-83. DOI: 10.1007/ s00268-016-3492-3

9. Dindo D, Demartines N, Clavien P-A. Classification of Surgical complications. A new proposal with evaluation in a cohort of 6336 patients and results of a survey. Ann Surg. 2004; 240(2):205-13. DOI: 10.1097/01.sla.0000133083.54934.ae

10. The 2012 European Ageing Report: Economic and budgetary projections for the 27 EU Member States (2010-2060). Annual Ageing Report.

11. De La Maisonneuve C, Oliveira Martins J. Public spending on health and long-term care: a new set of projections. OECD Economic Policy 2013; Paper N ${ }^{\circ} 6$.

12. Ljungqvist O, Scott M, Fearon KC. Enhanced Recovery after Surgery: a review. JAMA Surg. 2017;152(3):292-8. DOI: 10.1001/jamasurg.2016.4952

13. Singh PM, Panwar R, Borle A, Goudra B, Trikha A, van Wagensveld BA, Sinha A. Efficiency and safety effects of applying ERAS protocols to bariatric surgery: a systematic review with meta-analysis and trial sequential analysis of evidence. Obes Surg. 2017;27(2):489-501. DOI: 10.1007/s11695-016-2442-3 


\title{
Sažetak
}

\section{PRIMJENA PROGRAMA UBRZANOG OPORAVKA NAKON BARIJATRIJSKE KIRURGIJE: ANALIZA KLINIČKIH ISHODA I ISPLATIVOSTI}

\author{
V. Agnoletti, S. Bonilauri, L. De Pietri, D. Ferrara, A. Lanaia, N. Pipia, M. Seligardi, E. Padovani i R. M. Corso
}

Programi ubrzanog oporavka nakon operacije (Enhanced Recovery After Surgery, ERAS) su perioperacijske intervencije zasnovane na dokazima kojima je svrha učiniti perioperacijski tijek učinkovitijim osiguravajući bolesnikovu sigurnost i kvalitetu skrbi. Odnedavno je nekoliko sastavnica programa ERAS uvedeno u okruženje barijatrijske kirurgije (Enhanced Recovery After Bariatric Surgery, ERABS). Cilj ovoga istraživanja bio je procijeniti kliničku učinkovitost i isplativost provođenja programa ERABS. U ovoj retrospektivnoj studiji slučaja i kontrola uspoređena je skupina odraslih pretilih bolesnika (indeks tjelesne mase >40) liječenih prema protokolu ERABS (2014.-2015.) s povijesnom kontrolnom skupinom koja je primala standardnu skrb (2013.-2014.) u Klinici za opću i hitnu kirurgiju, Bolnica Arcispedale S. Maria Nuova, Reggio Emilia, Italija. Podaci o pojavnosti komplikacija, smrtnosti, ponovnom prijmu i ponovljenim operacijama retrospektivno su izvedeni iz bolesničkih kartona i prijamnih lista. Duljina boravka u bolnici značajno se razlikovala među dvjema skupinama bolesnika. U kontrolnoj skupini srednja duljina boravka u bolnici bila je 12,6 $\pm 10,9$ dana, dok je skupini ERABS iznosila 7,1 $\pm 2,9$ dana $(\mathrm{p}=0,02)$. Kod prijma se kirurška komplikacija razvila u 7 osoba iz kontrolne skupine; od toga je jedan bolesnik imao teže komplikacije, dok su u skupini ERABS manje komplikacije zabilježene kod 3 bolesnika. Ekonomska analiza pokazala je drukčiju raspoređenost troškova u dvjema skupinama. Sve u svemu, značajne uštede u gotovo svim ispitivanim varijablama uglavnom su nastale zbog isključenja uporabe jedinice intenzivnog liječenja, što je daleko skuplje od prosječnih troškova u jedinici skrbi poslije anestezije. Naše je istraživanje potvrdilo da primjena protokola ERABS skraćuje boravak u bolnici i snižava troškove pritom osiguravajući sigurnost bolesnika.

Ključne riječi: Bariatrijka kirurgija; Ubrzani oporavak nakon operacije; Troškovi 